\title{
Introduction to Private Law in Context
}

In 1960 William Twining was lecturing in common law at the University of Khartoum (Sudan). One day he was lecturing about a tort case in respect of a visitor to London Zoo. The visitor had been bitten by an Arabian camel and was injured. He sued the zoo and the legal question was whether the zoo was liable for negligence. ${ }^{1}$ At that moment Twining was interrupted by a student in the class who raised his hand and asked: 'Please, sir, why was the camel in the zoo?' At that moment some scales fell away from my eyes, Twining wrote, what had a camel in the zoo to do with Sudan? ${ }^{2}$ What's the point of lecturing common law to students to whom even the facts of the case make no sense (let alone the points of law)? It is hard to understand private law properly without familiarity with the context in which it finds its origin and application. So Twining made a plea for an alternative approach of the study of law, which he called 'law in context', and which aims 'to broaden the study of law from within', in accordance with the classic values of liberal education. ${ }^{3}$

This little story is the starting point for our quest into the nature of private law, our understanding of it, and the practice in which it finds its origin and application. Engaging upon such a quest - and nothing less - is the purpose of this book. Why should we do that? What might we learn from it? In most legal curricula private law is understood as doctrine, that is, as a system of rules and precedents. The doctrinal approach pretends to teach the student to think like a lawyer. ${ }^{4}$ This may work perfectly well until she runs into a hard case, or finds herself in a different context. The story of Twining reminds us that if the context changes, legal expertise that seemed adequate may turn into 'doctrine in a vacuum'. 5 The success and failure of legal education seems to depend on various contextual circumstances, both with regard to the educational context

McQuakerv. Goddard [1940] 1 KB 687.

William Twining, Law in Context, Enlarging Discipline (Oxford: Oxford University Press, 1997) 28.

3 Twining (n. 2) 2.

4 A terminological remark is pertinent here. When I refer to a 'lawyer' in this book I mean a jurist (in the broad sense), and not just an attorney or an advocate (unless the context indicates differently).

5 James Boyd White, 'Doctrine in a vacuum', in From Expectation to Experience, Essays on Law and Legal Education (Ann Arbor: The University of Michigan Press, 1999) 8-25. 
and with regard to the facts of the cases on which the doctrine has been built. So if we really want to understand private law as a socio-legal enterprise, we have to take all these circumstances into account again. Lawyers think and act 'pros ton kairon', as Aristotle wrote, according to the demands of the circumstances. ${ }^{6}$

In this Introduction I want to illustrate this starting-point and its implications by an elaborate example, drawn from the rulings of courts of two distinct jurisdictions on similar cases. The cases involve so-called 'foreign direct liability claims'; claims against a parent company for an alleged violation of a duty of care causing harm in another jurisdiction. In these particular cases Shell was sued for the pollution and environmental damage caused by the leaks of oil from pipelines in the Niger Delta in Nigeria. In 2015 the inhabitants of the area affected by the oil leaks filed legal claims in an English court of law against the parent company of the Shell group in London (RDS) and against Shell Nigeria (SPDC), both of which they held responsible for the damage. After the first court had ruled that there was no arguable case that RDS owed the claimants a duty of care (as required for jurisdiction), ${ }^{7}$ the claimants appealed to the UK Court of Appeal. ${ }^{8}$ The Court of Appeal dismissed the appeal with a majority of 2:1 (Lord Justice Sales dissenting). The question of whether RDS owed a duty of care towards those affected was assessed by the Court by means of the three-part test (set out in the Caparo case): foreseeability, proximity, and reasonableness. ${ }^{9}$ The requirement of proximity was the main obstacle for the claimants - so the Court ruled - since the evidence did not demonstrate a sufficient degree of control of SPDC's operations by the RDS. ${ }^{10}$ The claimants filed for appeal again and this time with success. ${ }^{11}$ The UK Supreme Court overturned the decision of the Court of Appeal, holding that both courts were drawn into a mini trial, which means that they were assessing the evidence produced instead of focusing on the question whether the claimants had an arguable claim (thus incorrectly excluding future evidence). Moreover, the Court pointed out several errors of law as well, as a consequence of an incor-

\footnotetext{
6 Aristotle, Nicomachean Ethics, Book II, Chapter 2, 4 (https://epdf.pub/the -nicomachean-ethics.html, available and last visited 18 March 2021).

7 Okpabi and others v. Royal Dutch Shell Plc and another [2017] EWHC 89 (TCC).

8 UK Court of Appeal (Civil Division) 14 February 2018 [2018] EWCA Civ 191 (Okpabi v. RDS).

9 Caparo Industries plc. v. Dickman [1990] 2 AC 605.

10 In the words of Lord Justice Simon: 'the concern was to ensure that there were proper controls and not to exercise control' (UK Court of Appeal (Civil Division) 14 February 2018 [2018] EWCA Civ 191, 125).

11 Okpabi and others v. Royal Dutch Shell Plc and another, 12 February 2021 [2021] UKSC 3.
} 
rect interpretation of the precedent in Vedanta. ${ }^{12}$ All in all, the appeal was allowed. Now it was up to the claimants to pursue their claims.

A few years before, several individual farmers from Nigeria (supported by a Dutch NGO) had already filed claims against RDS and SPDC in the Netherlands for the harm they had suffered as a consequence of distinct accidents with leaking pipelines. ${ }^{13}$ The District Court rejected the claims on their merits (with the exception of one claim against SPDC). The claimants appealed, however, and the Appellate Court ruled more favorably for them. ${ }^{14}$ Applying Nigerian law as the lex locus delicti, the Dutch Appellate Court was confronted with similar questions to the courts in London. ${ }^{15}$ On the grounds of established case law, the Dutch Appellate Court formulated the rule that, when the parent company knows or should know that the subsidiary negligently harms third parties in a domain over which the parent has control, it is under a duty of care to interfere. ${ }^{16}$ The court established that RDS knew, or at least should have known, that the local management in Oruma had failed to install a leak detection system (LDS), which constitutes a tort of negligence by SPDC. Moreover, the court established that RDS actively interfered with the use of LDSs in Nigeria for many years. The court ordered RDS to provide LDSs in the Oruma pipelines within one year. ${ }^{17}$

These cases illustrate that the debate in private law cases often transcends the strictly doctrinal arguments. Of course, the debate was primarily on the conditions under which the parent company Shell (RDS) would be liable for the negligence of its offspring SPDC in Nigeria. This involved a lot of doctrine as well as a detailed analysis of the actual influence of RDS on the operational affairs of SPDC in Nigeria. The argument in both the UK Supreme Court and the Appellate Court in The Hague focused on the internal company structure, policies, and practices of Shell. Although the two courts function in different jurisdictions, they were to apply the same law and thus addressed the same issues. The UK Supreme Court - ruling only two weeks after the Appellate

12 Lungowe v. Vedanta Resources Plc [2019] UKSC 20; [2020] AC 1045.

13 Since 2005, the parent company of the Shell group (RDS) has been based in London, while its main office is located in The Hague.

14 Court of Appeal The Hague 29 January 2021, ECLI:NL:GHDHA:2021:132 (Oguru/Shell Petroleum N.V.).

15 The court ruled that the sources of Nigerian law are the law of England (more particularly the common law of England and the doctrine of equity) and Nigerian legislation and case law.

16 With reference to UK Supreme Court 10 April 2019, [2019] UKSC 20 (Vedanta v. Lungowe).

17 Next to a declarative injunction that SPDC bears liability for the damage suffered as a consequence of this accident on 26 June 2005 by not installing an LDS before that date, and an injunction to instal such LDSs. 
Court in The Hague - even referred to the decision of the Dutch Court (with regard to the use of internal documents of Shell). ${ }^{18}$

However, there are differences as well. The Dutch Court was in the position to judge the claims on the merits, whereas the UK Supreme Court had to assess the question of whether the claimants had an arguable claim. Actually, this involved an estimation of the chances of success. Sometimes courts have to make a prognosis about the future. At other times, they use pragmatic arguments, referring to the consequences of their rulings. In both cases their judgments are not just backward-looking, but forward-looking as well. Another way in which judicial rulings transcend the realm of strictly doctrinal arguments is by referring - explicitly or implicitly - to moral or political arguments. In the opinion of Lord Justice Simon of the Court of Appeal, for example, it was held that it is important to distinguish the present context from the more abstract concepts of moral responsibility ('for example to reduce global warming and to protect the environment'). ${ }^{19}$ Cases like these easily transcend the strictly doctrinal, even if the debate is conducted primarily in doctrinal language. For this reason, we can only fully comprehend their meaning and purpose if we take context into account, or perhaps better, a variety of contexts.

The first context is of a conceptual nature: what is it that constitutes private law? How is it to be demarcated from, say, morals or practices? As we have noticed, courts sometimes appeal to moral arguments (if only in the negative), or to pragmatic arguments (referring to the consequences of their decisions). If the concept of private law is restricted to doctrine, the appeal to moral and pragmatic arguments is beyond its domain. Since courts actually make use of these arguments, this view seems too restrictive. But how do these moral and pragmatic arguments fit in the concept of private law? It seems we are in need of a conception of 'private law-in-context' that accounts for the relations between the doctrinal, the moral, and the empirical contexts of private law. This issue will be explored in Chapter 1.

The second context is the historical context: what has happened and when? Private law deals with historical facts, in the more or less remote past. The accident in Oruma took place on 26 June 2005, more than 15 years ago. It is a telling fact that during the Dutch trial - which started in 2008 - two of the original claimants had already died. Moreover, private law has its own history and it is worthwhile to follow its trail, for at least two reasons. First, it might help to get a better view of the jurisdictional borders we take for granted but which are actually the result of political, social, and legal developments (the rise and fall of European private law). Next, it offers an unorthodox perspective

18 UK Supreme Court (n. 11) para. 137.

19 UK Court of Appeal (n. 8) para. 88. 
on the development of legal scholarship, showing that the received view of doctrinal scholarship is itself the result of processes of external and internal differentiation. These developments will be explored in Chapter 2.

The third context is the rhetorical context: who is saying what to whom, when, and how? Civil cases are to represent orderly debates, governed by rules and principles of procedural law, giving each of the participants its due ('audi et alteram partem'). The rules of the debate determine what can be said, by whom, and when - and thus exclude certain arguments and viewpoints as legally irrelevant. Moreover, legal argument and legal interpretation presuppose an implicit context of firmly held convictions and attitudes that provide the standards for adequacy and relevance. Private law is a language game of its own, to use a familiar phrase of Wittgenstein. Becoming a private lawyer is to learn to speak its language, that is: to learn how it is spoken, and to find one's own voice. This is what the rhetoricians call ingenium, the power to make something new. ${ }^{20}$ The language of private law will be addressed in Chapter 3 .

The fourth context is the methodological context: how to argue, interpret, judge, and research? What do experts in private law know and what is the nature of their expertise? The courts were not all in agreement in the Nigerian cases, as happens more often than not. There seems to be room for disagreement here, not just in judging civil cases but also in private law scholarship. This raises difficult questions, however, on the nature of both civil adjudication and of legal scholarship. These questions are contested, but they are in need of satisfactory answers if private law is to be trusted as providing more than 'just' opinions. They will be addressed in several chapters. The kick-off will be an analysis of what private lawyers actually know and do when they are at work (Chapter 4). Against this background, the methodology of private law will be assessed, both of practitioners and of academics (Chapter 6). Finally, the disciplinary implications will be addressed. What is the position of private law scholarship in the spectrum of disciplines, from the sciences to the humanities and the social sciences (Chapter 7)?

The fifth context is the normative context: what moral and political arguments are in play? How and when do they interfere in the legal debate? How are they to be assessed? The claimants in the Dutch Nigerian cases celebrated the rulings of the Appellate Court as a victory. These rulings mark a symbol of justice for the poor farmers from Nigeria, holding a huge multinational responsible for its actions and negligence in the Niger Delta. The key value of private law is no doubt justice, but what other values are at play? How did they shape the form and content of private law in the course of its long history? In exploring these questions we cannot avoid the obvious fact that private law

20 James Boyd White (n. 5) 8-25. 
functions in a pluralistic society, characterized by competing conceptions of what constitutes the good life. Moreover, the courts and judges themselves may diverge in their value-orientation. How does private law function in this normative context of shifting moral and political values? This question will be explored in Chapter 5.

The sixth and last context is the professional one: who are we, as legal professionals? Private lawyers constitute a group of professionals who share certain expertise, values, and perhaps even a conception of what it is that makes them competent and trustworthy lawyers. Some of these conceptions are rather traditional, others are modern, and still others might be perceived as future-oriented. What they share is their orientation on professional values - such as upholding public trust, independence and autonomy, and public responsibility - although they may differ in their prioritization and interpretation of these values. Again, the individual lawyer has to find her way in this rapidly evolving professional context, wondering which conception suits her best and how she can make it her own. At the end of the day for each and every private lawyer the question is: who do I want to be, as a lawyer? This professional context will be explored in Chapter 8 .

These contexts do not exhaust the range of possible perspectives, of course, nor are they imperative. As we shall see in Chapter 1, the important questions in (private) law nevertheless boil down to three kinds of questions, which have been expressed by Julius Stone as 'Law as Logic', 'Law as Justice', and 'Law as Social Control'. His introduction to these questions serves well as an introductory note for this book as well: ${ }^{21}$

Anglo-American juristic interests have been largely concentrated, in the century since Austin, on the logic of the law, on the effort to view the precepts of the legal system in whole or in part as a logically self-contained system. Increasingly, however, the attention of a restless world is being directed towards two other questions. One of these is the question of justice. What are the ideals to which the legal order ought to conform? This is the central question of the theory of justice. The other question concerns law as a social reality. It inquires about the actual effects of the law upon men's attitudes and behaviour, and the effects of those upon the law. This brief series of questions sets the boundaries of the present work.

21 Julius Stone, The Province and Function of Law, Law as Logic Justice and Social Control, A study in Jurisprudence (London: Stevens \& Sons, 1947) vii. 